\title{
Application of Resource-Based-View Hrm Framework to Sales Training In Globacom Nigeria.
}

\author{
Clement Ikenna Okeke $(\mathrm{PhD})$ \\ Associate Professor, Head of Masters and PhD Programmes School of Management Sciences, National Open \\ University of Nigeria, Lagos.
}

\begin{abstract}
Using the Resource-Based-View Human Resource Management framework, this study sought to advance our understanding of the effects of training on organizational-level outcome by analyzing the impact of sales force training using GLOBACOM Nigeria, Enugu division as a case study. The study specifically addressed three training related questions that are important in the management of sales force in markets that are keenly competitive. Is the training conducted for the sales force relevant to the job? Does the frequency of the sales force training make it effective? What is the impact of sales force training on organizational performance in GLOBACOM Nigeria? To meet the data needs of the study, a structured questionnaire was administered on 136 officers of GLOBACOM Nigeria. Based on analyzed data and tested hypotheses, the following conclusions were drawn: GLOBACOM employees are aware of the forms of training, there is high employees' knowledge of and involvement in the training programmes provided by the company, the frequency of the sales force training does not make it effective, sales training conducted is related to the job description and hence relevant to the job of the sales force and Sales force training has no effect on organizational performance in GLOBACOM Nigeria. The study recommended the design of training policy, institutionalization of training assessment, undertaking of Training Impact Assessment and focusing on emergent important areas for sales force training in GLOBACOM Nigeria to produce positive organizational-level outcomes.
\end{abstract}

Key words: Organizational Performance, Resource-Based-View, Sales Force, Sales Force Training, and Training.

\subsection{Background Of The Study}

\section{Introduction}

The knowledge and skills of an organization's sales workforce have become increasingly important to its performance, competitiveness, and innovation (Lawler, Mohrman, \& Ledford, 1998[1]; Martocchio\& Baldwin, 1997)[2]. Workplace learning and continuous improvement are now considered essential for an organization to remain competitive (Salas \&Cannon-Bowers, 2001)[3]. Thus, it is not surprising that employee training is a multi-billion dollar industry worldwide (Haccoun\& Saks, 1998)[4]. In 2006, organizations in the United States spent a total of $\$ 55.8$ billion on training (Industry Report, 2006)[5]. According to Kraiger (2003), successful organizations are thought to invest more in training and development than other organizations [6]. The substantial outlay that organizations spend each year on formal training and development programs is made with the expectation that their training investments will lead to improvements in organizational performance or results (Dolezalek, 2005[7]; Salas \& Cannon-Bowers, 2001[3]). Although training is only one way for employee learning to occur, the investment made in training requires an analysis of the evidence to examine if, indeed, training pays off in organizational effectiveness.

However, training is often criticized for being faddish, too expensive, not transferring to the job, and not improving the bottom line (Caudron, 2002[8]; Kraiger, McLinden, \& Casper, 2004[9]; Salas, CannonBowers, Rhodenizer, \& Bowers, 1999[10]; Wright \& Geroy, 2001[11).

Training is often viewed as a cost center to be controlled or downsized during lean times (Kraiger, 2003[6]). Indeed, training programs are implemented for reasons other than improving performance such as legal compliance, rewarding and retaining employees, or because of training fads. There is skepticism about the link between training and results criteria. For example, Alliger, Tannenbaum, Bennett, Traver, and Shotland (1997, [12]) claimed that "most training efforts are incapable of directly affecting results level criteria".

Wright and Geroy (2001) [11] referred to the belief that training leads to improved organizational performance as a myth - "that equates training with 'goodness"'.

Research on the effects of training on results criteria remains sparse, especially at the organizational level of analysis. In fact, so few studies have included results criteria that a meta-analysis of the relations among Kirkpatrick's (1987)[13] four levels of training criteria was unable to include results (Alligeret al., 1997)[12]. Furthermore, most organizations still only evaluate training programs using reaction criteria, and very few measure the impact of training on results (Alligeret al., 1997[12]; Kraiger, 2003[6]; Kraiger et al., 2004[9]). Thus, when it comes to the effects of training on organizational outcomes or results criteria, there has not been 
the same degree of progress as there has been on the science and practice of training at the individual level of analysis (Kraiger, 2003[6]; Salas \& Cannon-Bowers, 2001[3]).

Training is defined as the systematic acquisition and development of the knowledge, skills, and attitudes required by employees to adequately perform a task or job or to improve performance in the job environment (Goldstein, 1980[14]; Latham, 1988[15]). Training should impart new knowledge and skills if the training is relevant, based on employee and organizational needs, and effectively designed and delivered (Salas et al., 1999[10]). When training does result in improvements in relevant knowledge and the acquisition of relevant skills, employee job performance should improve, provided that the skills learned in training transfer to the job (Salas et al., 1999[10]). Improvement in job performance should be reflected in organizational outcomes or results criteria such as productivity, quality, and service, if the job is strategically aligned to the organization's needs.

\subsection{Statement of Problem}

In spite of the continual debate, it seems that most sales managers and their organizations believe that salespeople are not simply born into their sales roles (Bragg, 1988[16]; Kelley, 1993[17]). Evidence of the fact that organizations are devoted to sales training may be found in the investments companies make in sales training. While training is obviously an important issue for firms, issues concerning the content and effectiveness of training continue to be discussed.

The primary research problem for this study can thus be presented as follows:

What form of sales force training most positively and effectively relates to organizational performance?

\subsection{Objectives of the Study}

The general objective of this study is to advance our understanding of the effects of training on organizationallevel outcome by analyzing the impact of sales force training on organizational performance using GLOBACOM Nigeria as a case study.

The specific objectives of the study are to determine:

If the training conducted for the sales force is relevant to the job.

If the frequency of the sales force training makes it effective.

The impact of sales force training on organizational performance in GLOBACOM Nigeria.

\subsection{Research Questions}

1. Is the training conducted for the sales force relevant to the job?

2. Are the employees aware of the forms of training in GLOBACOM?

3. Does the frequency of the sales force training make it effective?

4. What is the impact of sales force training on organizational performance in GLOBACOM Nigeria?

\subsection{Research Hypotheses}

$\mathrm{H}_{01}$ : GLOBACOM employees are not aware of sales force training.

$\mathrm{H}_{1} 1$ : GLOBACOM employees are aware of sales force training.

$\mathrm{H}_{02}$ : The frequency of sales force training does not make it effective.

$\mathrm{H}_{1}$ 2: The frequency of sales force training makes it effective.

$\mathrm{H}_{0} 3$ : The sales force training has no effect on organizational performance in GLOBACOM Nigeria.

$\mathrm{H}_{1} 3$ : The sales force training has an effect on organizational performance in GLOBACOM Nigeria.

\subsection{Significance of the Study}

Salespeople play an important role in gaining organizational outcomes in the positive direction. Liu and Comer (2007[18]) stated that "the input of salespeople has been found to be very important to the making of information source and promotion, capacity, or distribution decision. Salespeople are front line personnel; they are in a vantage position to feel the pulse of the market".

The concept of sales force training is relatively new and yet to be established. This study attempts to fulfill an evident research gap in effectiveness studies and to identify the impact of sales force training for Nigerian companies. This study offers one possible positioning for sales force training relative to some more established concepts.

Thus, the objective results provided by this research will be useful in facilitating the strategic role of sales force training, because sales training effectiveness will assist firms in promoting their strategic visions as well as achieve their companies' long-term goals. 
Application Of Resource-Based-View Hrm Framework To Sales Training In Globacom Nigeria.

\subsection{Definition of Related Terms} Sales Force

Sales force can be defined as the group of employees involved in the selling process (www.investorwords.com/4368/sales_force) [19].

It can also be defined as the division of a business that is responsible for selling products or services (www.entrepreneur.com/encyclopedia/sales-force) [20].

\section{Training}

Training is defined as the systematic acquisition and development of the knowledge, skills, and attitudes required by employees to adequately perform a task or job or to improve performance in the job environment (Goldstein, 1980[14]; Latham, 1988[15]). Training should impart new knowledge and skills if the training is relevant, based on employee and organizational needs, and effectively designed and delivered (Salas et al., 1999) [10].

\section{Sales Force Training}

Sales force training can be defined as a planned process to modify attitude, knowledge or skill through continuous learning experience, consistent coaching and feedback to all sales representatives to achieve effective performance in their sales activity in order to increase organizational performance/profitability. It also refers to the planned attempt by an organization to facilitate employee learning of job related knowledge, skills and behaviors (Dennis and Griffin, 2005[21]).

\section{Organizational Performance}

Organizational performance comprises the actual output or results of an organization as measured against its intended outputs (or goals and objectives).

\subsection{GLOBACOM Nigeria Limited: An Overview}

\section{Literature Review}

GLOBACOM Limited (or GLO) is Africa's fastest growing multinational telecommunications company headquartered in Lagos, Nigeria. GLO is a privately owned telecommunications carrier that started operations on 29 August 2003. GLO built an $\$ 800$ million high-capacity fiber-optic cable known as GLO-1, a submarine cable from the United Kingdom to Nigeria. Côte d'Ivoire.

It currently operates in four countries in West Africa, namely Nigeria, Republic of Benin, Ghana and

In August 2003, GLO Mobile was launched in Nigeria. GLO Mobile introduced lower tariffs; pay per second billing and alongside other value added services. Although GLO Mobile was the fourth GSM operator to launch in Nigeria, within seven years of the company's operation, its subscriber base has grown to over 25 million.

In 2005, GLO Mobile introduced the GLO Fleet Manager which is the most comprehensive Vehicle Tracking Solution offered. GLO Fleet Manager helps transporters/fleet operators manage their fleet. They also introduced the GLO Mobile internet service which provides subscribers with high speed access to all popular internet sites which have been customized for mobile phone browsing.

In 2006, GLO Mobile introduced BlackBerry. GLO started the sponsorship of the Confederation of African Football African Player of the Year Award. The company also started the sponsorship of GLO Lagos International Half Marathon.

In June 2008, GLO Mobile was launched in the Republic of Benin where it showed unprecedented growth through sale of 600,000 SIMs in first ten days of operation. GLO Mobile offered Per Second Billing, which charges subscribers for the exact airtime used. They also offered other value added services such as MMS (Multimedia Messaging Service), GLO Magic Plus news and information, vehicle tracking, musical ring-back tones and mobile banking.

In May 2008, GLO acquired an operating license through its GLO Mobile division in Ghana and plans to capture $30 \%$ of the current 11 million subscriber market within 18 months of launch. They plan on achieving this goal by launching bundled voice and Internet services for Ghana and through specifically targeting 'unserviced' areas outside Ghana's two major cities, Accra and Kumasi.

GLO Mobile was set to launch in Ghana the first quarter of 2010. In January 2012, GLO Ghana opened the "Reserve your number" campaign, but still without opening the network.

As of June 2009, the company has employed more than 2,500 people worldwide. GLO has an estimate of over 25 million subscribers (June 2009) and it is a 100 percent Nigerian owned company.

In 2009, GLO Mobile launched Blackberry prepaid services which gives subscribers options to pay daily, weekly or monthly for the service. Blackberry prepaid service gives subscribers free yahoo mail access 
Application Of Resource-Based-View Hrm Framework To Sales Training In Globacom Nigeria.

and free blackberry messenger. The company also launched 3G High Speed Internet services through the sale of its 3G modem. GLO Mobile 3G network is available in Lagos, Abuja, Benin and Port Harcourt. In October 2009, GLO acquired submarine cable landing rights and International Gateway Services in Côte d'Ivoire.

On April 8, 2011 GLO launched the sub-marine optical fiber GLO1, one part of its maiden operation in Ghana, to usher in another major player in the Ghana telecommunication industry

(www.en.wikipedia.org/wiki/GLOBACOM)[22].

\subsection{Theoretical Models of the Relationship between Training and Organizational-Level Outcomes}

Although there is a strong belief that training is related to organizational-level outcomes (Alliger $e t$ al., 1997) [12], the theoretical rationale for this relationship has seldom been the focus of training research. As noted by Kozlowski,Brown, Cannon-Bowers and Salas (2000)[23], most models of training end with the transfer of individual-level outcomes to the training context and there is little theoretical development or research on how individual-level training outcomes result in organizational-level outcomes. Thus, Kozlowski et al. (2000)[23] concluded that there is a levels gap in the training literature in which, although a goal of training is to enhance organizational effectiveness, the models, methods, and tools of training focus on the individual level.

The literature on strategic human resource management (SHRM) provides a number of models to explain how training might lead to organizational outcomes. For example, Wright and McMahan (1992)[24] provide a conceptual framework that incorporates six theoretical models for the study of SHRM. According to their framework and the theoretical models, HRM practices influence the HR capital pool and HR behaviors; HR behaviors then lead to firm level outcomes. Of the six theoretical models described in their framework, three of them are relevant for understanding training and organizational-level relationships. First, according to the resource-based view of the firm, an organization's resources can be a source of competitive advantage when it possesses resources that add positive value to the firm, are unique, imperfectly imitable, and cannot be substituted with another resource by competitors. Accordingly, human capital is considered to be a resource that can provide a competitive advantage to the extent that HR practices produce skilled employees who provide value to the firm and have unique inimitable skills. Applying the resource-based view to training suggests that training can be viewed as an investment in human capital that provides employees with unique knowledge, skills and abilities that add value to the firm and enable the performance of activities required to achieve organizational goals, thus resulting in positive organizational-level outcomes (Ostroff \& Bowen, 2000)[25].

The second theoretical model is the behavioral perspective which focuses on employee role behavior as a mediator between strategy and firm performance. Accordingly, human resource practices should elicit and reinforce the behaviors required by the organization's strategy. Along these lines, it is necessary to identify the HR practices that will be most effective for eliciting desired role behaviors. The desired role behaviors should then lead to positive organizational outcomes. Applying the behavioral perspective to training suggests that training will result in positive organizational outcomes to the extent that it results in employee behaviors that are required by the organization's strategy.

The third theoretical framework is represented by a set of models, described as cybernetic systems models or input- throughput-output models (Wright \& McMahan, 1992) [24]. Open system models portray organizations as transforming inputs from the environment into outputs. Wright and McMahan (1992)[24] present a cybernetic open systems model of HR in which inputs consist of employees' knowledge, skills and abilities (KSAs); the throughput is employee behaviors; and output includes productivity, satisfaction, and turnover. Included under the cybernetic approach is an open systems model of the HR system in which employee competencies (inputs) lead to behaviors (throughputs) which then lead to affective and performance outcomes (outputs). Thus, when applied to training, cybernetic models suggest that training leads to organizational outcomes to the extent that it results in competencies (i.e., knowledge, skills, and abilities) that are necessary to perform the behaviors that will impact organizational outcomes. Kozlowski et al. (2000) [23] provided a theoretical framework to develop a multilevel model of training effectiveness to bridge the micromacro gap in the training literature. Kozlowski et al. (2000) [23] proposed that "Training effectiveness involves the linkage between micro training outcomes and macro objectives at higher organizational levels". They focused on training transfer "because it is the primary leverage point by which training can influence organizational effectiveness" and present a theoretical framework to guide research on vertical transfer (i.e., upward transfer across different levels of the organizational system). Kozlowski et al. (2000) [23] distinguished between two types of vertical transfer processes: composition and compilation. With composition, individual contributions are additive and compensatory because they involve the same content (e.g., as in a typing pool). The averaged combination of individual-level KSAs, behavior, and performance will lead to higher-level outcomes. With compilation, individual contributions are conjunctive and individuals contribute different or diverse content (e.g., as in a surgical team or a flight crew). Thus, different skills and behaviors need to combine across positions in order for vertical transfer to occur. 
Regardless of the combinatorial rules, it is individual KSAs, behaviors, and performance that are imparted through training and are the precursor of vertical transfer. Training leads to organizational-level outcomes to the extent that it results in the acquisition of KSAs, behaviors, and performance that are necessary to achieve desired organizational outcomes.

In summary, the theories reviewed in this section suggest that the effect of training on organizationallevel outcomes is mediated through direct effects of training on employee attitudes, behaviors, and KSAs. As Ostroff and Bowen (2000)[25] theorized, an HR system is a complex set of practices designed to influence employees' collective satisfaction, commitment, motivation, behavior and skills; these attributes are thought to be the mediating mechanism that links HR practices and firm performance.

According to Ostroff and Bowen (2000) [25], employees' collective attitudes, behaviors, and human capital should influence organizational performance. In turn, organizational performance should lead to positive financial outcomes for the organization (Becker \& Huselid, 1998[26]; Dyer \& Reeves, 1995[27]), mediating the relationship between human resource outcomes and financial performance.

\section{Research Methodology}

To be able to answer the questions of sales force training forms, relevance, frequency and impact, and to test the two formulated hypotheses for acceptance and/or rejection, the study relied on a structured questionnaire that was administered on officers of GLOBACOM in Enugu division. Enugu is the capital of Enugu state in south east Nigeria and served as one of the eight divisions of GLOBACOM as at 2013. In terms of revenue size by which the divisions are categorized, Enugu was number 6 division. The other divisions were Lagos (1), Benin (2), Abuja (3), Kano (4), Port Harcourt (5, Jos(7) and Akure (8). The sales staff strength of Enugu division as at October 2013 was 400.

The questionnaire contained three sections: the first was the respondents' data and questions designed to capture employees' awareness of training; the second section aimed to identify the forms and frequency of training as perceived by employees; the third section sought information about sales force training and organizational performance. The questions that addressed the research questions were framed on a five likert scale ranging from 1-5, with 5 indicating strongly agree, and 1 indicating strongly disagrees. The draft questionnaire was subjected to a pretest to enhance its validity and reliability as a measuring instrument. Substantial modifications followed the pretest exercise that included the inclusion of new questions to fill identified gaps, recasting of ambiguous questions and dropping of redundant ones.

From the study population of 400, the sample size was determined at 200 using Taro Yamani formula for sample size determination for a finite population at $5 \%$ maximum acceptable error.

The questionnaire was administered to the sales force of GLOBACOM Nigeria Limited, Enugu who were available and willing to complete it within the three days the exercise lasted (October 7-9, 2013).Two hundred (200) questionnaires were distributed and one hundred and thirty six (136) were duly completed and returned giving a response rate of $68 \%$ which formed the basis for the analysis.

Descriptive statistics in the form of frequency of the sales force training programmes and percentages were used to summarize and organize the data while chi-square was conducted to investigate the effect of sales force training on organizational performance.

\subsection{Demographic Analysis}

\section{Data Analysis And Result Presentation}

Table 1 below showed that there were $71(52.2 \%)$ males and $65(47.8 \%)$ females. The table also showed that $51(37.5 \%)$ of the respondents were single, the married were $78(57.4 \%)$, the divorced accounted for $5(3.6 \%)$ while the separated were $2(1.5 \%)$. The academic qualification of the respondents showed that 21 (15.4\%) had the Postgraduate certificates, 63 (46.3\%) had BSC (Bachelor of Science), HND (Higher National Diploma) certificates, OND (Ordinary National Diploma) and NCE (National Certificate in Education) certificates, $50(36.8 \%)$ attained secondary school education, while $2(1.5 \%)$ had other certificates. About 31.6 $\%$ of the respondents have been employed in their current job for more than five years.

Table 1: Profile of Respondents

\begin{tabular}{|l|l|l|}
\hline Gender & Frequency & Percentage (\%) \\
\hline Male & 71 & 52.21 \\
Female & 65 & 47.79 \\
Total & 136 & 100.0 \\
\hline Marital Status & Frequency & Percentage $(\%)$ \\
\hline Single & 51 & 37.50 \\
Married & 78 & 57.35 \\
Divorced & 05 & 03.68 \\
Separated & 02 & 01.47 \\
Total & 136 & 100.0 \\
\hline
\end{tabular}


Application Of Resource-Based-View Hrm Framework To Sales Training In Globacom Nigeria.

\begin{tabular}{|l|l|l|}
\hline Academic Qualification & & \\
\hline Post graduate & 21 & 15.44 \\
BSC, HND OND, NCE & 63 & 46.32 \\
Senior Secondary School & 50 & 36.77 \\
Others & 02 & 01.47 \\
Total & 136 & 100.0 \\
\hline Work Experiences (yrs.) & Frequency & Percentage (\%) \\
\hline $1-5$ & 93 & 68.38 \\
$6-10$ & 23 & 16.91 \\
$11-15$ & 20 & 14.71 \\
Total & 136 & 100.0 \\
\hline
\end{tabular}

Source: Field Survey, 2013

\subsection{Analysis According To Research Questions}

In this section, data related to research questions are analyzed.

Research Question One: 'what is the perception of employees in terms of awareness of the sales force training? Answering this question involved mapping out employees' knowledge of and involvement in the training programmes provided by the company. Findings showed that there was a relatively high level of awareness of the training activities provided by the company in that $73.53 \%$ of the employees reported various degree of awareness to the trainings as shown in table 2 below.

Table 2: Awareness of Forms of Sales Force Training in GLOBACOM Nigeria

\begin{tabular}{|l|l|l|}
\hline Response & Frequency & Percentage \\
\hline Strongly Agreed & 60 & 44.12 \\
\hline Agreed & 40 & 29.41 \\
\hline Undecided & 02 & 01.47 \\
\hline Disagreed & 24 & 17.65 \\
\hline Strongly Disagreed & 10 & 07.35 \\
\hline Total & 136 & 100 \\
\hline
\end{tabular}

Source: Field Survey, 2013

Research Question Two: Is the training conducted for the sales force relevant to the job?

The data from the table below showed that $55.88 \%$ agreed that sales training conducted is related to the job description and hence relevant to the job of sales people while $44.12 \%$ disagreed. This is a mixed response. While majority agreed, a significant minority disagreed.

Table 3: Sales Training Relates to Job Description of Sales Force in GLOBACOM Nigeria

\begin{tabular}{|l|l|l|}
\hline Response & Frequency & Percentage \\
\hline Strongly Agreed & 30 & 22.06 \\
\hline Agreed & 46 & 33.82 \\
\hline Undecided & 00 & 00 \\
\hline Disagreed & 60 & 44.12 \\
\hline Strongly Disagreed & 0 & 00 \\
\hline Total & 136 & 100 \\
\hline
\end{tabular}

Source: Field Survey, 2013

Research Question Three: Does the frequency of the sales force training make it effective?

Data on table 4 on question three showed that $44.11 \%$ of the respondents agreed that frequency of training is leading to its effectiveness in GLOBACOM, $14.71 \%$ are undecided while $41.18 \%$ disagreed. This is another close call that makes conclusion difficult

Table 4: Frequency Leading to Effectiveness of Sales Force Training in GLOBACOM Nigeria.

\begin{tabular}{|l|l|l|}
\hline Response & Frequency & Percentage \\
\hline Strongly Agreed & 26 & 19.11 \\
\hline Agreed & 34 & 25.00 \\
\hline Undecided & 20 & 14.71 \\
\hline Disagreed & 36 & 26.47 \\
\hline Strongly Disagreed & 20 & 14.71 \\
\hline Total & 136 & 100 \\
\hline
\end{tabular}

Source: Field Survey, 2013

Research Question Four: What is the impact of sales force training on organizational performance in GLOBACOM Nigeria? 
Data on table 5 below showed that a marginal majority of $54.41 \%$ agreed that sales training in GLOBACOM enhances workers as well as organizational performance.44.12\% of the respondents however disagreed. This is yet another close call.

The findings above showed that sales force training bring about organizational performance. This finding is also consistent with the findings of Delery and Doty [28], (1996); Becker and Huselid, (1998) [26]; Collins, Buhalis and Peters (2003)[29]; Evans and Lindsay (1999)[30]; and Jones (2005)[31] who found considerable effect of employee training on organizational performance.

Table 5: GLOBACOM's Sales Training and Enhancement of Workers as well as Organizational Performance.

\begin{tabular}{|l|l|l|}
\hline Response & Frequency & Percentage \\
\hline Strongly Agreed & 10 & 07.35 \\
\hline Agreed & 64 & 47.06 \\
\hline Undecided & 02 & 01.47 \\
\hline Disagreed & 40 & 29.41 \\
\hline Strongly Disagreed & 20 & 14.71 \\
\hline Total & 136 & 100 \\
\hline
\end{tabular}

Source: Field Survey, 2013

\section{3: Test of Hypotheses}

The 3(three) hypotheses formulated for the study were tested at $95 \%$ confidence level using $\mathrm{Z}$ test of proportion for data generated from 136respondents surveyed.

The formula used for $\mathrm{Z}$ statistics is:

$\begin{array}{lll}\mathrm{Z} & = & \frac{\mathrm{x}-\mathrm{np}}{\sqrt{\mathrm{np}}(1-\mathrm{p})} \\ \text { Where } & \\ \mathrm{x} & = & \text { respondents supporting Ho } \\ \mathrm{n} & = & \text { sample size } \\ \mathrm{p} & = & \text { probability for Ho acceptance }(50 \%)\end{array}$

Decision rule: Reject Ho and accept Hi when the computed $\mathrm{Z}$ value is greater than the absolute Z.05 (+-1.96) and accept Ho when the computed $\mathrm{Z}<$ the absolute value of $\mathrm{Z} 0.05$.

\section{Hypothesis One}

H0: GLOBACOM employees are not aware of sales force training.

H1: GLOBACOM employees are aware of sales force training.

Table 4.2 revealed that $\mathrm{n}=136, \mathrm{X}=34$ and $\mathrm{P}=0.5$

Computed $Z=-1$.

Given that $\mathrm{Z}(-1)$ is within the acceptance region of +-1.96 , the study accepted Ho and concluded that GLOBACOM employees are not aware of sales force training.

\section{Hypothesis Two}

H0: The frequency of the sales force training does not make it effective.

$\mathrm{H} 1$ : The frequency of the sales force training makes it effective.

Table 4.4revealed that $n=136, x=56$ and $\mathrm{p}=0.5$

Computed $\mathrm{Z}=-0.35$.

Given that computed Z (-0.35) is within the acceptance region of Ho, the study concluded that the frequency of the sales force training does not make it effective.

\section{Hypothesis Three}

H0: The sales force training has no effect on organizational performance in GLOBACOM Nigeria.

H1: The sales force training has an effect on organizational performance in GLOBACOM Nigeria.

Table 4.5 revealed that $\mathrm{n}=136, \mathrm{X}=60$ and $\mathrm{P}=0.5$.

Computed $\mathrm{Z}=-0.24$.

Given that computed $\mathrm{Z}(-0.24)$ is within the acceptance region of Ho (+-1.96), the study concluded that the sales force training has no effect on organizational performance in GLOBACOM Nigeria. 
Application Of Resource-Based-View Hrm Framework To Sales Training In Globacom Nigeria.

\subsection{Summary of Findings}

\section{Summary Of Findings, Conclusion And Recommendations}

1) A marginal majority of 55.88\% agreed that sales training conducted is related to the job description and hence relevant to the job of the sales force

2) $73.53 \%$ of the employees reported various degree of awareness to the sales force training activities of GLOBACOM Nigeria.

3) The frequency of the sales force training does not make it effective.

4) Sales force training has no effect on organizational performance in GLOBACOM Nigeria.

\subsection{Conclusion}

This study established that sales force training should impact individual and organizational performance. Firms in the telecommunication industry should therefore formulate and implement strategic training and development policy: they should develop a strong training culture. This policy and training culture should help develop human capital by training all and sundry without discrimination and politicking. Besides, for training to be effective, it must be frequent, as the recent changes in employee skills set due to increasing Globalization with its resultant competition require newer skills set through constant training. To be effective also sales training conducted should be related to the job description and hence relevant to the job of sales

\subsection{Managerial Implications and Recommendations}

This study may have important implications for practice.

The findings pointed to negative reactions toward training opportunities being insufficient and infrequent in terms of obtaining high levels of organizational outcomes. Therefore, the findings would help management to address this low level of perceived training opportunities for employees which may lead to lower levels of organizational outcomes in the telecommunications industry in the future.

The findings also pointed to the importance of training and development efforts as an integral part of higher organizational performances. This should motivate training and development opportunities in other telecommunication companies.

The following key recommendations are made:-

\section{Design and Adoption of a Training Policy}

To make training relevant and effective at the individual and organizational levels there is need to institutionalize it through the adoption of a training policy. The policy document will establish who should be trained, how, when, where and what he should be trained on. The major benefit of a training policy is to remove arbitrariness in the conduct of training in organizations. For this to be systematic, training needs analysis should be the takeoff point of training in the system. This will establish on a continuous basis the training needs of individuals, units/departments and the organization. This will bring about greater awareness on the part of officers and their input.

Ultimately, the policy will spell out the training each officer is entitled to, when he will go for the training, the frequency and methods/processes of training to be adopted.

\section{Institutionalization of Training Assessment}

To derive value for money and ensure that training impacts on both individual and organizational performance, training should consistently be assessed at the pre training phase, training phase and post training phase. The objective of assessment is to sustain and validate the gains of training against the backdrop of its established objectives.

\section{Undertaking of Training Impact Assessment}

Though sales training should be person-centred, at least in the long-run, investment in training should conduce to greater organizational performance and achievement of corporate goals and objectives. This can be achieved through proper tracking of the on the job performance of officers who have been trained. Rapid impact assessment that is done three months after training will help in establishing why trained officers are performing or not performing as expected and remedial measures taken to ensure full utilization of learned knowledge, skills and attitudes by the sales force.

\section{Emerging Important Areas of Sales Force Training}

The training of sales force should in addition to selling skills and product knowledge cover the following emerging areas:

- Product belief

- Company belief 
- Information gathering/marketing intelligence

- Know your customers

- Know your competitors

- Professionalism and ethical considerations in selling

- Personal effectiveness and remaining healthy.

- Relationship management

- Debt collection and credit management.

\section{References}

[1]. E.E. Lawler, S.A. Mohrman and G.E. Ledford (1998). Strategies for high performance organizations-The CEO report San Francisco: Jossey-Bass Publishers.

[2]. J.J. Martocchio and T.T. Baldwin (1997). The evolution of strategic organizational training. Research in Personnel and Human Resources Management, $15,1-46$.

[3]. E. Salas and J.A. Cannon-Bowers (2001). The science of training: a decade of Progress, Annual Review of Psychology, 52, 471-499.

[4]. R.R. Haccoun and A.M. Saks (1998). Training in the 21st century: some lessons from the last one. Canadian Psychology, 39(1-2), $33-51$

[5]. Industry Report (2006). \$56 billion budgeted for formal training. Training, 43(12), 20-32.

[6]. K. Kraiger (2003). Perspectives on training and development, in W. C. Borman, D. R. Ilgen, \& R. J. Klimoski (Eds.), Handbook of Psychology: Industrial and Organizational Psychology (pp. 171-192). Hoboken, NJ: John Wiley \& Sons.

[7]. H. Dolezalek(2005). 2005 industry report. Training, 42(12), 14-28

[8]. S. Caudron (2002). Just say no to training fads. Training and Development, 56(6), 40-43.

[9]. K. Kraiger, D. McLinden and W.J. Casper (2004). Collaborative planning for training impact,. Human Resource Management, 43 , 337-351.

[10]. E. Salas, J.A. Cannon-Bowers, L. Rhodenizer and C.A. Bowers (1999). Training in organizations.research, in Personnel and Human Resources Management, 17, 123-161.

[11]. P.C. Wright and G.D. Geroy (2001). Changing the mindset, International Journal of Human Resource Management, 12, 586-600.

[12]. G. M. Alliger, S. I. Tannenbaum, Bennett, W.H.Traver and A.Shortland (1997). A meta-analysis on the relations among training criteria. Personnel Psychology, 50,341-358.

[13]. D.L. Kirkpatrick (1987). Evaluation of training, in R. L. Craig (Ed.), Training and development handbook (pp. 301-319). New York: McGraw-Hill.

[14]. I. Goldstein (1980). Training in work organizations, Annual Review of Psychology, 31, 229-272.

[15]. G.P. Latham (1988). Human resource training and development, Annual Review of Psychology, 39, 545-582.

[16]. A. Bragg (1988), "are good salespeople born or made?" Sales and Marketing Management, (September), pp. 74-78.

[17]. B. Kelley (1993). Training: just plain lousy or too important to ignore?" Sales and Marketing Management, (March), pp. 66-70.

[18]. S.S. Liu and L.B. Comer (2007). Salespeople as information gatherers: associated success factors, .Industrial Marketing Management, No: 36, pp. 565-574.

[19]. www.investorwords.com/4368/sales_force

[20]. www.entrepreneur.com/encyclopedia/sales-force

[21]. A.S. Dennis and R.W.Griffin (2005). Human resource management. Boston, NY, Houghton Mifflin Company.

[22]. www.en.wikipedia.org/wiki/GLOBACOM

[23]. S. Kozlowski, K. Brown, D. Weissbein, J. Cannon-Bowers and E. Salas (2000). A multilevel approach to training effectiveness, in K. Klein, \& S. Kozlowski (Eds.), Multi-Level Theory, Research, and Methods in

[24]. Organizations (pp.157-210). San Francisco, CA: Jossey-Bass.

[25]. P. M. Wright, and G. C. McMahan, (1992). Theoretical Perspectives for Strategic Human Resource Management.Journal of Management, 18, 295-320

[26]. C. Ostroff and D.E. Bowen (2000). Moving HR to a higher level: HR practice and organizational effectiveness, in K. J. Klein, \& S W. Kozlowski (Eds.), Multilevel theory, research, and methods in organizations (pp. 211-266). San Francisco, CA: Jossey-Bass

[27]. B. E. Becker and M.A.Huselid (1998). High performance work systems and firm performance. Research in Personnel and Human Resources Management, 16, 53-101.

[28]. L. Dyer and T. Reeves (1995). Human resource strategies and firm performance. International Journal of Human Resource Management, 6, 656- 670 .

[29]. J.E. Delery and D.H. Doty (1996). Modes of theorizing in strategic human resource management. Academy of Management Journal, 39, 802-835.

[30]. C. Collins, G. Buhalis and F.Peters (2003). Enhancing SMTEs business performance through the internet and e-learning platform. Education and

[31]. Training, 45(8/9), 483-494

[32]. J.R. Evans and W.M. Lindsay (1999). The management and control of quality. (4th ed.), Cincinnati, Ohio: South-Western College Publishing.

[33]. J.T. Jones (2005). The determinants of training in australian manufacturing SMEs. Education and Training, 47(8/9), 605-615

\section{ABOUT THE AUTHOR}

Dr C. I. Okeke holds a PhD in Marketing from Abia State University, Uturu, Abia State, Nigeria. He is an Associate Professor and Head of PhD and Masters Programmes Unit in National Open University of Nigeria, Lagos. He was previously a Director of Research and Consultancy in the Centre for Management Development, Lagos and Director General of Abuja Graduate School, Abuja, Nigeria 